\title{
Sistem Informasi Penerimaan Peserta Didik Baru Online Berbasis Website di Yayasan Pendidikan Arya Jaya Sentika
}

\author{
Taufik Hidayat*, Mahmudin Muttaqin, Djamaludin \\ Program Studi Teknik Informatika, Fakultas Teknik, Universitas Islam Syekh Yusuf \\ Jl. Maulana Yusuf No.10 Babakan, Kota Tangerang, Indonesia 15118 \\ *email: thidayat@unis.ac.id
}

(Naskah masuk: 25 Januari 2020; diterima untuk diterbitkan: 24 Februari 2020)

\begin{abstract}
ABSTRAK - Penerimaan Peserta Didik Baru merupakan langkah awal dalam manajemen pelayanan sekolah kepada masyarakat dalam dunia pendidikan. Bagaimana sebuah sekolah melakukan promosi produk dan sekaligus pelayanan prima diawali dari penerimaan peserta didik, selanjutnya siswa/orang tua akan mendapatkan akses portal. Penelitian ini menggunakan metode waterfall dalam melakukan rancang bangun sistem informasi penerimaan peserta didik baru, metode waterfall adalah suatu metode yang merupakan perancangan System Development Life Cycle (SDLC), dimana perancangan diawali dengan requirement, design, implementation, verification dan maintenance. Teknik pengumpulan data melalui observasi lapangan, wawancara, dan studi literature. PHP (HyperText Markup Language) merupakan Bahasa pemograan berbasis website bersifat server-side, yang berarti kode program PHP diproses seluruhnya di dalam web server. MySQL merupakan bahasa yang memiliki kemampuan cukup baik untuk menunjang kerja para developer, baik User yang sudah berpengalaman dengan database maupun untuk pemula. Pada penelitian ini calon atau orang tua siswa dapat melakukan pendaftaran peserta didik baru dengan online, mengetahui pembayaran biaya masuk sekolah sekaligus dapat melakukan cetak bukti pembayaran Dana Sumbangan Pendidikan (DSP). Dari hasil penerapan PPDB Online di Yayasan Arya Jaya Sentika dengan cara memberikan kuesioner kepada 63 responden, terdiri dari guru, wali murid, calon wali murid, alumni, penduduk dan pengurus yayasan maka diperoleh nilai $68.32 \%$, dengan predikat setuju.
\end{abstract}

Kata Kunci - Penerimaan Peserta Didik Baru; DSP; SDLC; PHP; SQL.

\section{Information System of Student Admission by Website-Information SystemBased Online at the Arya Jaya Sentika Education Foundation}

\begin{abstract}
Acceptance of new student admission is the first step in the management of public services in the world of education. How the school performs prime product promotion and services are initiated by acceptance of new student admission, then students or parents will get portal access. This research uses waterfal method in designing information systems for admission of new students. Waterfal method is a method which is the design of the System Development Life Cycle (SDLC), where design begins with requirement, design, implementation, verification and maintenance. Data collection techniques through field observation, interview and literature study. PHP (Hyper Text Markup Language) is a web based programming language which contains servier side. MySQL is a language that has good ability to support the work of developers. User who had experienced with databases and for beginners. In this research prospective students or parents can register via online, Knowing the entry fee and can do print evidence for the payment of the education contribution fund. The results of the online PGDP implementation of Arya jaya sentika with giving questionnaire to 63 of the respondents, consisting of teachers, trustees, students, alumni, citizens and trustees, thereby earning $68.32 \%$, with agree predicate.
\end{abstract}

Keywords - Acceptance of New Students; DSP; SDLC; PHP; SQL 


\section{PENDAhuluaN}

Penerimaan Peserta Didik Baru (PPDB) merupakan langkah atau proses awal yang dilakukan penyelenggara pendidikan baik tingkat dasar ataupun tinggi. Berdasarkan Peraturan Menteri Pendidikan dan Kebudayaan nomor 44 Tahun 2019, BAB I Pasal 2. Tentang Penerimaan Peserta Didik Baru pada Taman Kanak-Kanak, Sekolah Dasar, Sekolah Menengah Pertama, Sekolah Menengah Atas dan Sekolah Menengah Kejuruan, PPDB dilakukan berdasarkan: a. nondiskriminatif; b. objektif; c. transparan; d. akuntabel; dan e. berkeadilan. (2) Nondiskriminatif sebagaimana dimaksud pada ayat (1) dikecualikan bagi Sekolah yang secara khusus melayani peserta didik dari kelompok gender atau agama tertentu[1]. Sistem Informasi Menurut Hutahaean, "Sistem informasi adalah suatu sistem di dalam suatu organisasi yang mempertemukan kebutuhan pengelolaan transaksi harian, mendukung operasi, bersifat manajerial, dan kegiatan strategi dari suatu organisasi dan menyediakan pihak luar tertentu dengan laporanlaporan yang dibutuhkan"[2]. "Menurut Tanggela, Pakareng, \& Wenas secara garis besar sistem informasi berasal dari dua kata yaitu sistem dan informasi. Sistem yang berarti suatu kesatuan utuh yang terdiri dari beberapa bagian yang saling berhubungan dan berinteraksi untuk mencapai tujuan tertentu sedangkan informasi merupakan data yang disampaikan, sehingga sistem informasi memiliki arti yaitu suatu cara tertentu untuk menyediakan yang dibutuhkan oleh organisasi untuk beroperasi dengan cara yang sukses"[3].

Sistem informasi terdiri dari empat komponen yaitu: aktivitas manajemen, kualitas informasi, struktur keputusan, dan aplikasi sistem informasi. Dari keempat komponen itu terdapat definisi masing-masing yaitu:

a. Aktivitas manajemen sistem informasi terkadang diklasifikasikan berdasarkan aktifitas yang didukungnya. Berdasarkan hal ini, terdapat pengelompokan pada level manajemen. Menurut Ebert dan Griffin dalam Kadir, pengelompokannya mencakup sistem informasi pengetahuan, sistem informasi operasional, sistem informasi taktis, sistem informasi strategis[4].

b. Kualitas informasi menurut $\mathrm{O}^{\prime}$ Briens, di dalam winda septianita mengatakan "tingkat dimana informasi memiliki karakteristik isi, bentuk, dan waktu, yang memberikannya nilai buat para pemakai akhir tertentu" [5].

c. Aplikasi sistem informasi suatu rangkaian sourcecode, kumpulan tabel di dalam database yang saling berinteraksi digerakkan oleh sebuat intruksi yang berorientasi objek dan memiliki algoritma dalam pengambilan keputusannya, dinyatakan berhasil dan cukup apabila telah.

Di bawah ini berupa penelitian sebelumnya, dengan judul Penerapan Model Waterfall Pada Perencanaan Siswa Baru SMK Swasta Teladan Rantauprapat Berbasis Web, penulis Ibnu Rasyid Munthe, pada jurnal ilmiah AMIK Labuan Batu Vol.5 No.3 September 2017, hasil dari penelitian membuat system informasi pendaftaran siswa baru pada SMK untuk mempermudah pendaftaran siswa baru, persamaannya terletk pada pembuatan system PPDB berbasis web, kalebihannya membuat system yang mudah dilihat, perbedaan terletak pada notifikasi berupa pemberitahuan melalui email setelah diverifikasi oleh admin[6]. Artikel selanjutnya dengan judul Aplikasi Pendaftaran dan Penerimaan Siswa Baru di SMK Negeri 1 Rupat berbasis Web dan SMS Gateway, penulis Siti Suherni, Nur Rubiati, Hayatullah Khumaini. Pada Jurnal Informatika, Manajemen dan Komputer, Vol.9 No.2 Desember 2017, hasil membuat aplikasi PPDB berbasis web dan SMS Gateway, persamaannya terletak pada aplikasi berbasis web, kelebihan yaitu notifikasi menggunakan SMS Gateway, perbedaan terletak pada notifikasi berupa pemberitahuan melalui email setelah diverifikasi oleh admin[7].

Terdapat tiga komponen utama yang digunakan pada penelitian ini, di antaranya: 1) PPDB, yaitu Penerimaan Peserta Didik Baru yang familiar dengan akronim PPDB adalah penerimaan peserta didik untuk jenjang taman kanak-kanak, sekolah dasar dan sekolah menengah pertama yang dilaksanakan pada awal tahun pelajaran baru[8], 2) MySQL, merupakan Database Server yang bersifat Open Source, Multiplatform dan Berbasis database relasional. MySQL dapat dipakai untuk database pribadi atau pada level korporat berskala kecil hingga besar. MySQL menggunakan SQL untuk mendukung pengaksesan data (query)[9], 3) CodeIgniter, yaitu sebuah framework atau biasa disebut kerangka kerja, dimana cara kerjanya membagi antara unit kontrol, unit data/model dan unit tampilan/view, CodeIgniter sangat popular dikalangan developer web dikarenakan sifatnya terbuka dan multi platform sehingga ringan dan mudah untuk digunakan [10]. Gambar 1 dan Gambar 2 merupakan model dan arsitektur View Controller yang digunakan pada penelitian ini. 


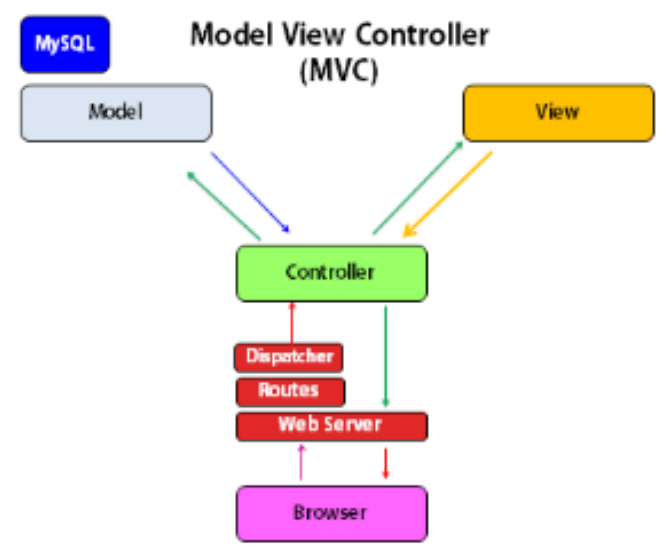

Gambar 1. Model View Controller (MVC)[10].

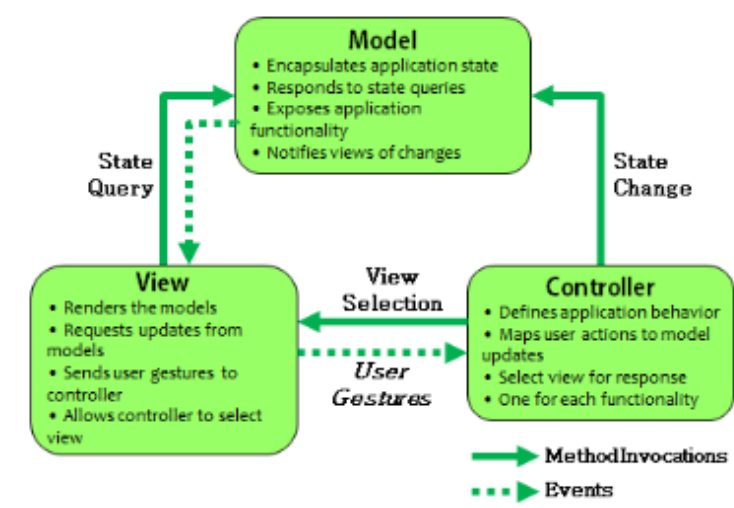

Gambar 2. Architectural Model View Controller (MVC)[10].

Pada penelitian ini calon atau orang tua siswa dapat melakukan pendaftaran peserta didik baru dengan online, mengetahui pembayaran biaya masuk sekolah sekaligus dapat melakukan cetak bukti pembayaran Dana Sumbangan Pendidikan (DSP). PPDB Online pada Yayasan Pendidikan Arya Jaya Sentika diharapkan dapat memfasilitasi informasi dan media untuk orang tua siswa baru dalam melakukan pendaftaran lebih efektip dan efisien, serta dapat melakukan cetak dan mengetahui informasi biaya DSP. Dana Sumbangan Pembangunan merupakan dana yang umumnya diberikan oleh perorangan secara fisik. Pemberian ini mempunyai sifat secara sukarela tanpa adanya imbalan[11]. Dalam aplikasi PPDB ini orang tua siswa akan mendapatkan informasi pembayaran DSP (Dana Sumbangan Pendidikan), persyaratan dan pelaksanaan kegiatan belajar mengajar (PKBM). Orang tua siswa baru akan mendapatkan notifikasi setelah diverifikasi oleh panitia PPDB, dalam pengembangan PPDB ini dibatasi pada tingkat taman kanak-kanak dan sekolah dasar, belum menggunakan virtual account sebagai media pembayaran, belum melaksanakan tes online dan CBT.

\section{Metode Penelitian dan BAHAN}

2.1 Metode Pengumpulan Data

Dalam menyelesaikan pembangunan sistem informasi PPDB Online di Yayasan Pendidikan Arya Jaya Sentika Berbasis Web dari itu penulis telah melakukan penelitian dengan menggunakan metode terstruktur. Dengan melakukan wawancara, observasi lapangan dan melakukan pengumpulan data mulai dari formulir PPDB, rincian biaya PPDB, panitia PPDB, brosur PPDB hingga promosi PPDB pada website sekolah.

\subsection{Metode Perancangan Sistem}

Perancangan sistem penerimaan peserta didik baru menggunakan metode waterfall sehingga akan diketahui runtut maju dalam proses kegiatan perancangan, dalam metode waterfall memiliki kelebihan, yaitu: terencana, detail pengerjaan lebih teliti, disiplin dalam setiap phase pekerjaan, tidak memerlukan biaya yang tinggi. Waterfall adalah model pengembangan sistem yang setiap tahapnya harus diselesaikan terlebih dahulu secara penuh sebelum diteruskan ketahap berikutnya untuk menghindari terjadinya pengulangan tahapan[12]. Kerugian dari metode waterfall ini adalah menghabiskan waktu pekerjaan yang cukup panjang, bilamana ditemukan masalah maka harus meruntut mundur setiap phase.

Penjelasan dari tahap-tahap waterfall model adalah sebagai berikut:

a. Requirements analysis and definition Layanan sistem, kendala, dan tujuan ditetapkan oleh hasil konsultasi dengan pengguna yang kemudian didefinisikan secara rinci dan berfungsi sebagai spesifikasi sistem[13].

b. Design. Proses ini digunakan untuk mengubah kebutuhan-kebutuhan diatas menjadi representasi ke dalam bentuk "blueprint" software sebelum coding dimulai[14].

c. Implementation and unit testing Pada tahap ini, Sistem sudah siap diterapkan atau sudah mulai siap digunakan oleh pengguna sehingga tidak ada lagi kesalahan ketika sistem sudah diimplementasikan[15].

d. Pengujian Pada tahap ini program yang telah dibuat harus diuji coba agar tidak terjadi error dan hasilnya harus sesuai dengan kebutuhan yang telah didefinisikan[3].

e. Operasi dan Maintenance Ini merupakan tahap terakhir dalam model waterfall. Software yang sudah jadi dijalankan serta dilakukan pemeliharaan. Pemeliharaan termasuk dalam memperbaiki kesalahan yang tidak ditemukan pada langkah sebelumnya. Perbaikan implementasi unit sistem dan peningkatan jasa system sebagai kebutuhan baru[16]. 


\subsection{Analisa Kebutuhan}

Usulan bisnis proses dari sistem informasi penerimaan peserta didik baru meliputi:

a. Halaman Awal, Pada halaman Awal akan di tampilkan Tombol Login dan Daftar dan juga popup alur pendaftaran dan lain lain, Pada halaman Daftar ditampikan form untuk mengisi biodata untuk kelengkapan sang siswa seperti orang tua, identitas anak, asal pendidikan dan juga berkas foto seperti Kartu Keluarga, Akte Lahir dan juga Kartu Tanda Penduduk Orang Tua, Pada halaman Login seorang user atau admin akan mengisikan NISN dan Password untuk masuk kedalaman Dashboard user ataupun Dashboard admin

b. Halaman User, Halaman Beranda, dihalaman ini di tampilkan ketentuan pembayaran dan jumlah pembayaran pendaftaran yang harus di lunasi, Halaman Status Pembayaran, dihalaman ini di tampilkn pembayaran pendaftaran yang telah di bayar dan juga bisa juga mencetak pembayaran melalui tombol cetak pembayaran.

c. Halaman Admin, Halaman Beranda, halaman beranda akan menampilkan total pendaftar SD dan TK, menampilkan total Siswa SD dan TK dan juga akan menampilkan grafik pendaftar SD dan TK per bulan, Halaman Pendaftar, pada halaman ini akan menampilkan pendaftar SD dan TK yang akan di aktivasi dan juga membayar sebagian uang untuk pembayaran. Halaman Aktivasi, pada halaman ini akan di tampilkan form untuk mengisi nomor induk siswa, tanggal di terima di sekolah dan juga pembayaran atau biaya pendaftaran yang harus di isi, Halaman Detail, halaman ini akan menampilkan detail siwa pendaftar yang pendaftar daftar seperti identitas anak, orang tua dan juga berkas. Halaman Siswa, dihalaman ini akan menampilkan daftar anak atau siswa TK ataupun siswa SD yang telah di aktivasi. Halaman Edit Siswa, dihalaman ini kita bisa mengedit data siswa seperti identitas dan juga pembayaran ketika ingin melunasi pembayaran pendaftaran. Halaman Detail Siwa, dihalaman ini kita bisa melihat detail seorang siswa seperti identitas anak dan juga pembayaran yang telah di lunasi. Halaman Setting Pendaftaran, pada halaman berisi form yang bisa kita setting seperti Buka dan Tutup pendaftaran dan Tahun pendaftaran dan juga tanggal, bulan pendaftaran tersebut untuk di tampilkan di halaman awal. Halaman Tambah admin untuk membuat User admin untuk login admin.

\section{HASIL DAN PEMbahasan}

\subsection{Use Case Diagram}

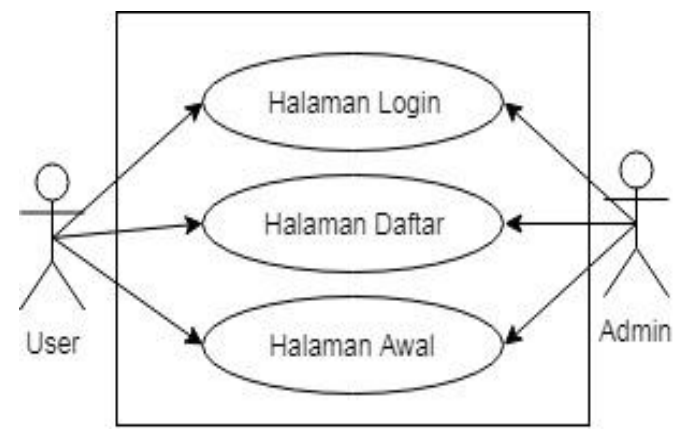

Gambar 3. Use case sistem informasi PPDB

Gambar 3 memperlihatkan use case sistem informasi PPDB. Pada halaman awal akan menampilkan tombol login dan rombol daftar untuk user, pendaftar calon siswa baru dan admin untuk halaman login akan menampilkan form NIS dan juga password untuk digunakan pada saat login ke dalam dashboard user dan admin.

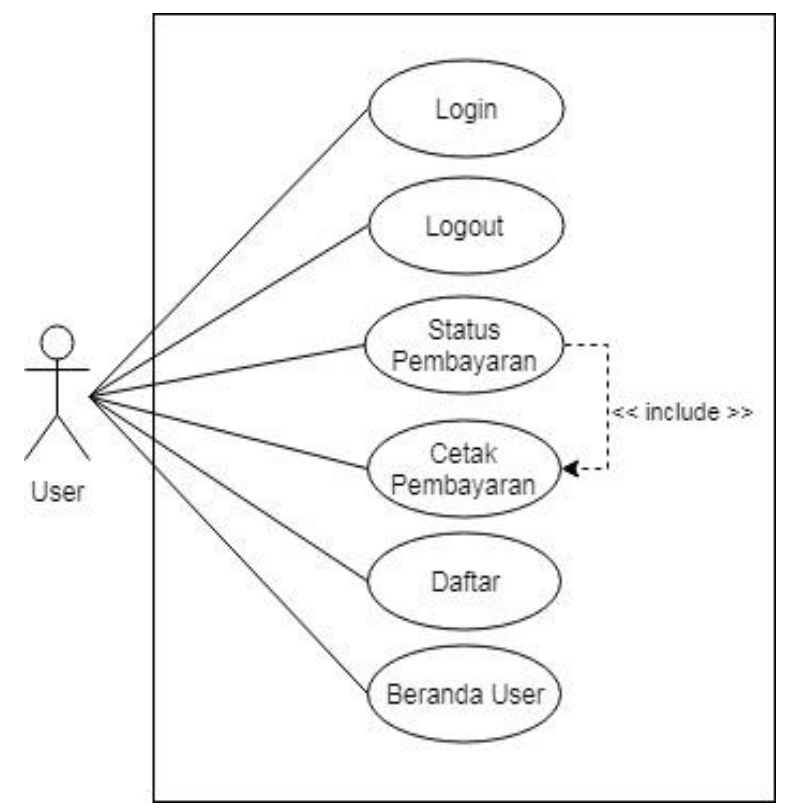

Gambar 4. Dashboard user

Gambar 4 menampilkan use case pada bagian dashboard user. Pada halaman dashboard user akan ditampilkan halaman beranda, halaman pembayaran user dan logout. 


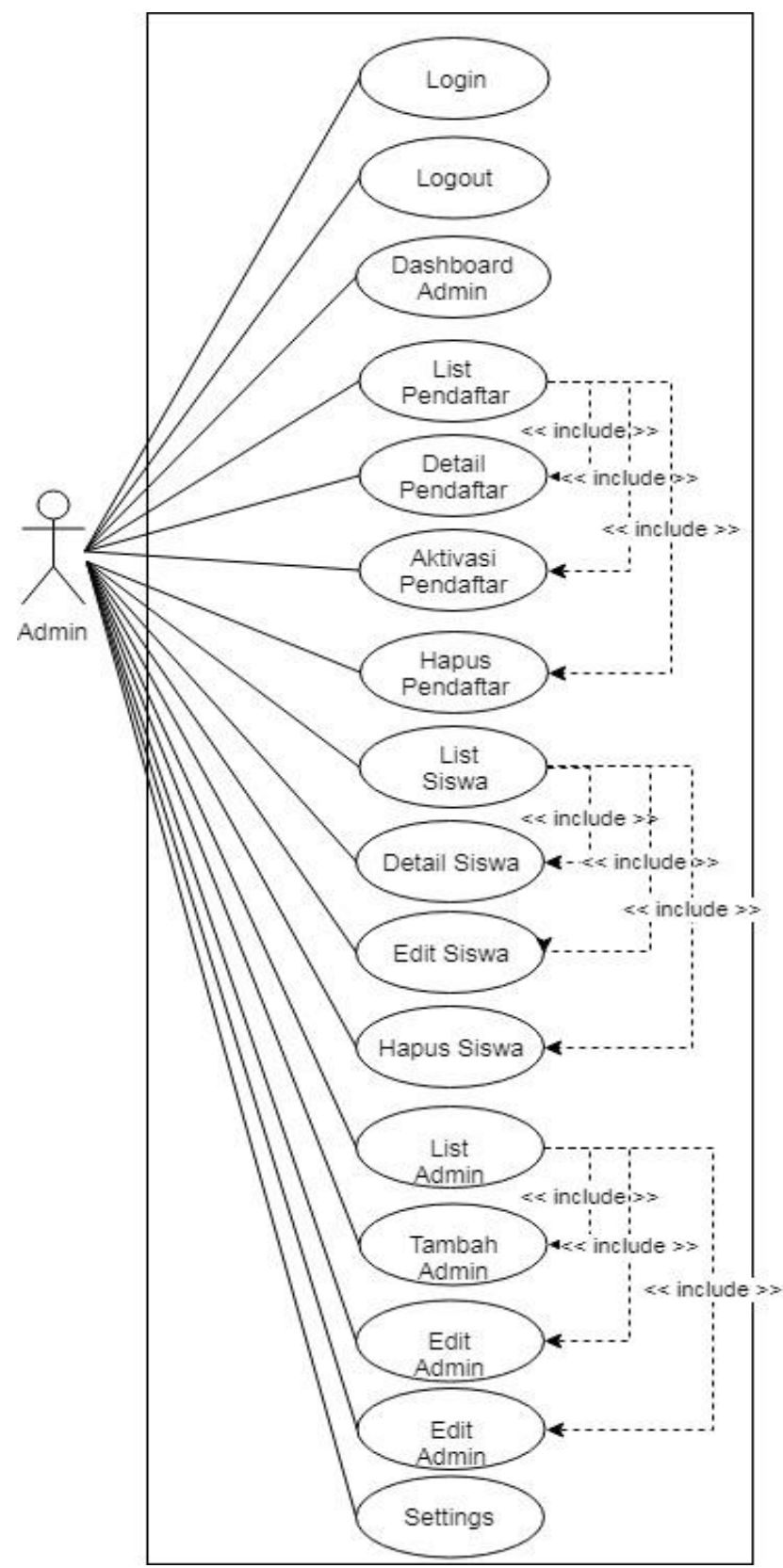

Gambar 5. Dashboard Admin

Setelah admin berhasil login admin maka akan tampil dengan halaman dashboard admin. Use case dashboard Admin diperlihatkan pada gambar 5 . Pada halaman dashboard admin terdapat menu pendaftaran, list siswa dan setting pendaftaran.

Tabel 1. Users

\begin{tabular}{llcl}
\hline \multicolumn{1}{c}{ Nama } & Tipe & Ukuran & Keterangan \\
\hline Id & Int & 11 & Untuk id \\
Nis & Int & 15 & Untuk nim \\
Nisn & Int & 15 & Untuk NISN \\
Nama & Varchar & 100 & Untuk Nama \\
Jenjang & Varchar & 100 & jenjang \\
Password & Varchar & 100 & Password \\
Id_admin & Int & 11 & Tipe tipe role \\
Created_at & Datetime & & Tanggal \\
& & & pembuatan \\
\hline
\end{tabular}

Tabel 1 merupakan tabel user yang dipergunakan oleh aplikasi PPDB, dimana masing-masing memiliki nama, tipe, ukuran, dan keterangan, dengan Primar Key Id user.

Tampilan halaman depan ditampilkan pada Gambar 6.
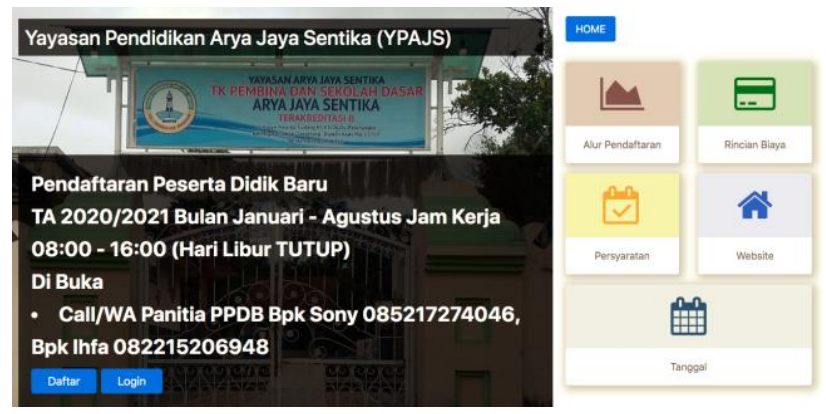

Gambar 6. Tampilan Awal

Menu login yang ditunjukkan pada Gambar 8 akan tampil manakala sudah memilih tombol pilihan sekolah yang ada pada gambar 7 .

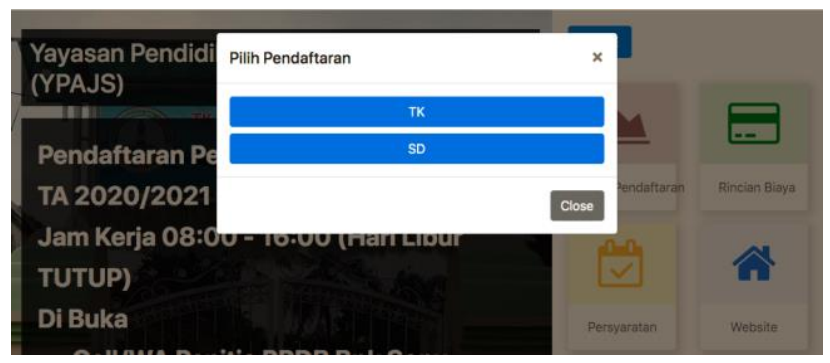

Gambar 7. Tampilan Awal Popup Daftar

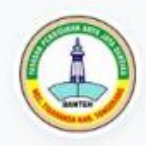

Login

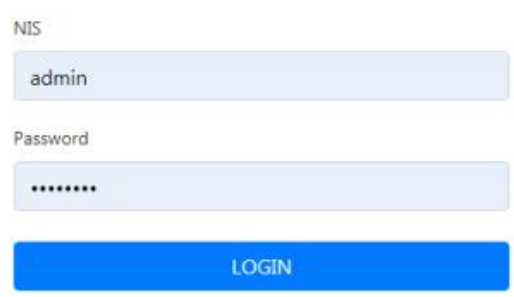

Gambar 8. Tampilan Login

Selanjutnya, calon siswa baru dapat melakukan input pendaftaran pada formulir dengan lengkap secara online, setelah semuanya diisikan kemudian disimpan, maka langkah selanjutnya calon siswa akan menunggu untuk mendapatkan balasan email (notifikasi) seperti yang ditampilkan pada Gambar 9. 


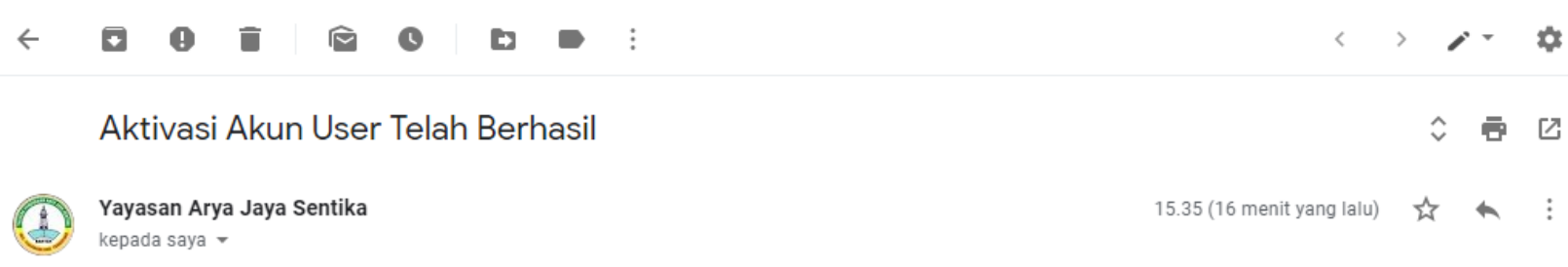

\section{Terima kasih telah mendaftar di Yayasan Pendidikan Arya Jaya Sentika}

Akun sudah berhasil di aktivasi silahkan login dengan NIS: 121. dan Password: 121

Halaman Login

Gambar 9. Notifikasi email aktivasi

\section{Apakah anda setuju dengan PPDB ONLINE AJS}

63 tanggapan

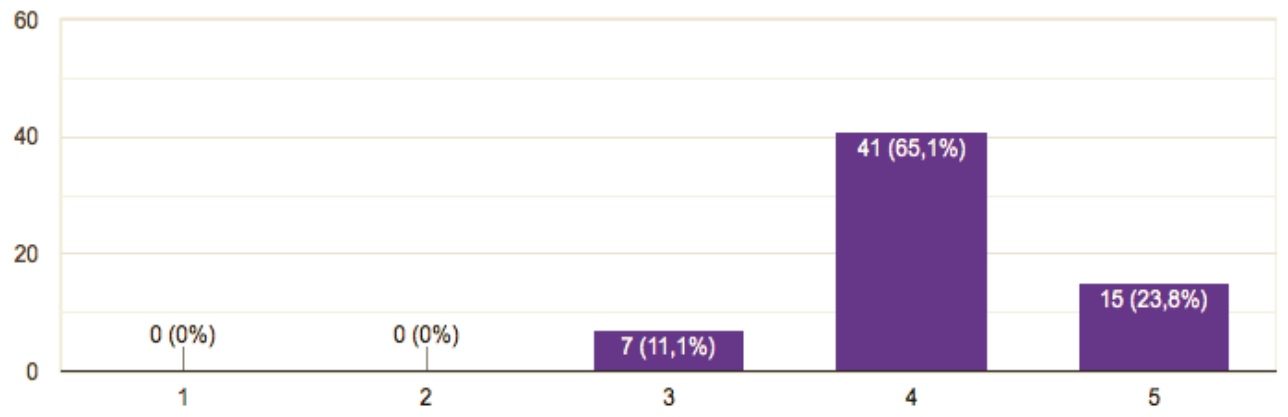

Gambar 10. Instument pengujian

Gambar 9 merupakan notifikasi setelah calon siswa baru tersebut selesai melakukan pendaftaran dan pembayaran melalui loket pembayaran sekolah, dimana selanjutnya akan mendapatkan portal layanan informai seputar PPDB dan sekolah.

\subsection{Hasil tes responden}

Pengujian dilakukan dengan menggunakan angket yang disebar kepada responden sebanyak 63 responden. Hasil penyebaran angket diperoleh hasil seperti ditunjukkan pada Gambar 10.

Tabel 2. Interval Penilaian[17].

\begin{tabular}{ccc}
\hline Indeks & Rentang & Keterangan \\
\hline 1 & $0 \%-19,99 \%$ & Sangat Tidak Setuju \\
2 & $20 \%-39,99 \%$ & Tidak Setuju \\
3 & $40 \%-59,99 \%$ & Ragu - ragu \\
4 & $60 \%-79,99 \%$ & Setuju \\
5 & $80 \%-100 \%$ & Sangat Setuju \\
\hline
\end{tabular}

Tabel 2 merupakan interval penilaian dari hasil pengujian yang dibagikan kepada responden terhadap penilain sistem PPDB.
Tabel 3. Tabel Skor

\begin{tabular}{cccccc}
\hline No & A & B & C & D & E \\
\hline 1 & 0 & 0 & 7 & 41 & 15 \\
2 & 0 & 12 & 22 & 24 & 5 \\
3 & 0 & 2 & 13 & 34 & 10 \\
4 & 0 & 6 & 17 & 28 & 12 \\
5 & 0 & 0 & 16 & 37 & 10 \\
6 & 0 & 6 & 16 & 33 & 8 \\
7 & 0 & 0 & 2 & 42 & 19 \\
8 & 0 & 0 & 32 & 24 & 7 \\
9 & 0 & 5 & 11 & 35 & 12 \\
\hline Skore & 0 & 31 & 136 & 298 & 98 \\
\hline
\end{tabular}

Tabel 3 merupakan perhitungan nilai skor dari hasil pengujian sistem PPDB.

Penyelesaian akhir :

$=$ Total Skor $/ \mathrm{Y} \times 100$

$=2152 / 315 \times 100$

$=68,32 \%$

$=\mathrm{SETUJU}$ 


\subsection{Blackbox Testing}

Tabel 4 merupakan hasil dari pengujian dengan menggunakan BlackBox Testing, untuk mengetahui sejauhmana tampilan dan unjuk kerja serta responsibilitas sistem PPDB pada saat dipergunakan oleh user.

\begin{tabular}{clc}
\multicolumn{4}{c}{ Tabel 4. Testing } & \\
\hline No & Sekenario & Kesimpulan \\
\hline 1 & $\begin{array}{l}\text { User Login mengisi NIS dan } \\
\text { Password yang benar }\end{array}$ & Valid \\
2 & $\begin{array}{l}\text { Admin Login mengisi NIS } \\
\text { dengan Password yang benar }\end{array}$ & Valid \\
3 & $\begin{array}{l}\text { User Login mengisi NIS dan } \\
\text { Password yang benar }\end{array}$ & Valid \\
4 & $\begin{array}{l}\text { Admin Login mengisi NIS } \\
\text { dengan Password yang benar }\end{array}$ & Valid \\
5 & $\begin{array}{l}\text { User Mendaftarkan Diri dengan } \\
\text { menenak Tombol daftar dan }\end{array}$ & Valid \\
memilih SD ataupun TK. & \\
6 & $\begin{array}{l}\text { User menekan menu halaman } \\
\text { Status Pembayaran setelah } \\
\text { masuk halaman Dashboard User. }\end{array}$ & Valid \\
& User telah mengisi form \\
pendaftaran dan menekan \\
tombol finish.
\end{tabular}

Hasil dari responden yang memberikan kontribusi dalam pengujian Sistem Informasi Penerimaan Peserta Didik Baru Online berbasis Website. Terdiri dari 63 (enam puluh tiga) responden yang terdiri dari unsur Pengurus Yayasan, Kepala sekolah, Guru, masyarakat calon wali murid dan alumni. Dari hasil tersebut diperoleh $68,32 \%$ menyatakan setuju.

\section{KESIMPULAN}

Kesimpulan dari penelitian ini Sistem informasi PPDB dapat melakukan pendaftaran secara online, orang tua calon siswa baru dapat mengetahui biaya dan mendapatkan informasi biaya dana sumbangan pendidikan, sistem akan mengirimkan notifikasi email ketika pendaftar telah membayar sekaligus dapat mencetak buktinya, orang tua siswa baru akan mendapatkan username dan password untuk dapat login ke sistem. Untuk mengetahui alamat websitenya dapat dilihat pada alamat website https://ppdb.ajs.sch.id/.

\section{UCAPAN TERIMA KASIH}

Terima kasih kami ucapkan kepada jajaran pengurus Yayasan Pendidikan Arya Jaya Sentika (YPAJS), yang telah memberikan izin kepada kami melakukan penelitian di Taman Kanak-kanak dan Sekolah Dasar di lingkungan YPAJS, sehingga terbangunnya aplikasi Sistem Informasi Penerimaan Peserta Didik Baru online berbasis website.

\section{DAFTAR PUSTAKA}

[1] Kementrian Pendidikan dan Kebudayaan Republik Indonesia, "Penerimaan Peserta Didik Baru," 2014. [Online]. Available: https://www.kemdikbud.go.id/main/blog/20 19/12/permendikbud-tentang-penerimaanpeserta-didik-baru-ppdb. [Accessed: 16-Dec2019].

[2] I. Sadikin dan U. Rusmawan, "Sistem pengolahan data penerimaan siswa baru dan pembayaran spp pada smk karya guna 1 bekasi," Methodika, vol. 3, no. 1, pp. 251-257, 2017.

[3] T. Hidayat, T. A. Priambodo, dan D. Agustine, "Perancangan Website Sistem Informasi Akademik Sekolah Dasar ( Studi Kasus: SDS Arya Jaya Sentika - Tigaraksa Kabupaten Tangerang )," SATIN - Sains dan Teknol. Inf., vol. 4, no. 2, p. 1, 2019.

[4] M. Pradana, "Perencanaan Skema Sistem Informasi Untuk Aktivitas Manajemen," Ekombis Rev., vol. 4, no. 1, pp. 65-71, 2016.

[5] W. Septianita, W. A. Winarno, dan A. Arif, "Pengaruh Kualitas Sistem, Kualitas Informasi, Kualitas Pelayanan Rail Ticketing System (RTS) Terhadap Kepuasan Pengguna (Studi Empiris Pada PT. Kereta Api Indonesia (PERSERO) DAOP 9 Jember)," e-Journal Ekon. Bisnis dan Akuntansi, 2014, Vol. 1 53-56, vol. 1, no. 1, pp. 5356, 2014.

[6] I. R. Munthe, "Penerapan Model Waterfall Pada Perancangan Sistem Informasi Pendaftaran Siswa Baru Smk Swasta Teladan Rantauprapat Berbasis Web," J. Ilm. AMIK Labuhan Batu, vol. 5, no. 3, pp. 15-21, 2017.

[7] S. Suherni, N. Rubiati, dan H. Khumaini, "Aplikasi Pendaftaran dan Penerimaan Siswa Baru dii SMK Negeri 1 Rupat Berbasis Web Dan SMS Gateway," Informatika, vol. 9, no. 2, p. 15, 2019.

[8] D. Purwanti, I. Irawati, dan J. Adiwisastra, "Efektivitas Kebijakan Penerimaan Peserta Didik Baru Sistem Zonasi Bagi Siswa Rawan Melanjutkan Pendidikan," Dinamika, vol. 5, no. 4, pp. 1-7, 2018.

[9] M. F. Wicaksono, "Implementasi Modul Wifi Nodemcu Esp8266 Untuk Smart Home," J. Tek. Komput. Unikom, vol. 6, no. 1, pp. 1-6, 2017.

[10] H. Hustinawati, A. K. Himawan, dan L. Latifah, "Performance Analysis Framework Codeigniter and Cake PHP in Website Creation," Int. J. Comput. Appl., vol. 94, no. 20, pp. 6-11, 2014.

[11] J. Juniko, E. Hernawati, M. B. Sanjaya, “Aplikasi Administrasi Pembayaran Sumbangan Pembinaan Pendidikan (SPP) dan Dana Sumbangan Pembangunan (DSP) di SD Ananda Bojong Kulur Kabupaten Bogor", e-Proceeding of 
Applied Science, 2019, vol. 5, no. 3, pp. 1891-1901.

[12] A. Oktarino, "Perancangan Sistem Nformasi Rekam Medis Pasien Pada Klinik Bersalin Kasih Ibu Menggunakan Metode Waterfall," Sci. J. No.3, vol. 4, no. 3, pp. 239-247, 2015.

[13] G. W. Sasmito, "Penerapan Metode Waterfall Pada Desain Sistem Informasi Geografis Industri Kabupaten Tegal," J. Inform. Pengemb. IT, vol. 2, no. 1, pp. 6-12, 2017.

[14] N. Blacklock and C. Blacklock, "Waterfalls", Gooseberry, vol. XII, no. 01, pp. 41-56, 2018.

[15] F. Z. Hambali, W. Witanti, dan P. N. Sabrina, "Pembangunan Sistem Electronic Customer
Relationship Management pada PT. Beton Elemenindo Perkasa", Komputika J. Sist. Komput., vol. 8, no. 1, pp. 1-11, 2019.

[16] S. T. Safitri dan D. Supriyadi, "Rancang Bangun Sistem Informasi Praktek Kerja Lapangan Berbasis Web dengan Metode Waterfall," J. INFOTEL - Inform. Telekomun. Elektron., vol. 7, no. 1, p. 69, 2015.

[17] V. H. Pranatawijaya, W. Widiatry, R. Priskila, dan P. B. A. A. Putra, "Penerapan Skala Likert dan Skala Dikotomi Pada Kuesioner Online," J. Sains dan Inform., vol. 5, no. 2, p. 128, 2019. 